\title{
Liposarcoma of the Cord presenting at Vasectomy Counselling
}

\author{
Major S M Milner \\ BDS, FRCS(Ed), RAMC
}

\section{Squadron Leader I E Hawthorn \\ FRCS(Ed), RAF}

\section{Wing Commander B T Morgans FRCS(Glas), RAF}

Department of Surgery, Princess Alexandra Hospital Wroughton, Royal Air Force Wroughton, Swindon, Wilts SN40QJ

SUMMARY: A case of liposarcoma of the cord is reported in a patient presenting for vasectomy.

This paper discusses such tumours and illustrates the importance of a careful clinical examination during counselling.

\section{Case Report}

A 36 year old man was referred for vasectomy, and during the counselling he gave a 14 year history of nagging scrotal pain. Clinical examination revealed normal testes with a soft mass, thought to be an epididymal cyst, above the left testis. In view of the clinical findings, scrotal exploration was carried out under general anaesthetic and the testicle was delivered prior to vasectomy. A partly encapsulated fatty lesion was found to be infiltrating and surrounding both testicle and cord. The tumour was dissected free with some difficulty and excised.

Histological examination revealed a well differentiated liposarcoma. This was infiltrating the epididymis and was surrounding but not involving blood vessels and nerves. Most of the tumour resembled a vascular lipoma, but in other parts diagnostic features of multivesiculated primitive cells, bizarre hyperchromatic multi-nucleated forms and granular lipoblasts were seen.

In view of the histological finding the patient underwent a left radical orchidectomy with high ligation of the cord 10 days later. An ellipse of skin was taken from around the original incision and biopsies taken of retroperitoneal fat and lymph nodes. Histology revealed no residual tumour and showed only reactive changes in the retroperitoneal tissue and lymph nodes.

The patient has remained free of recurrence for 4 years supported by CT scans.

\section{Discussion}

Liposarcoma is a malignant, infiltrating neoplasm characterised by the presence of atypical lipoblasts (Fig 1). Its occurrence in the spermatic cord is very uncommon as it forms only $4.3 \%$ of all tumours of the epididymis, paratesticular tissue and spermatic cord..$^{1,2}$ Liposarcomas originate in primitive mesenchymal cells rather than mature adipose tissue and are not believed to occur in pre-existing lipomas. Five histological variants are recognised in the World Health
Organisation classification, ${ }^{3}$ and the well differentiatedtype carries the best prognosis. In Enzinger's series ${ }^{4}$ it had a 5 year survival rate of $85 \%$.

Radical orchidectomy with high ligation of the cord $\vec{\omega}$

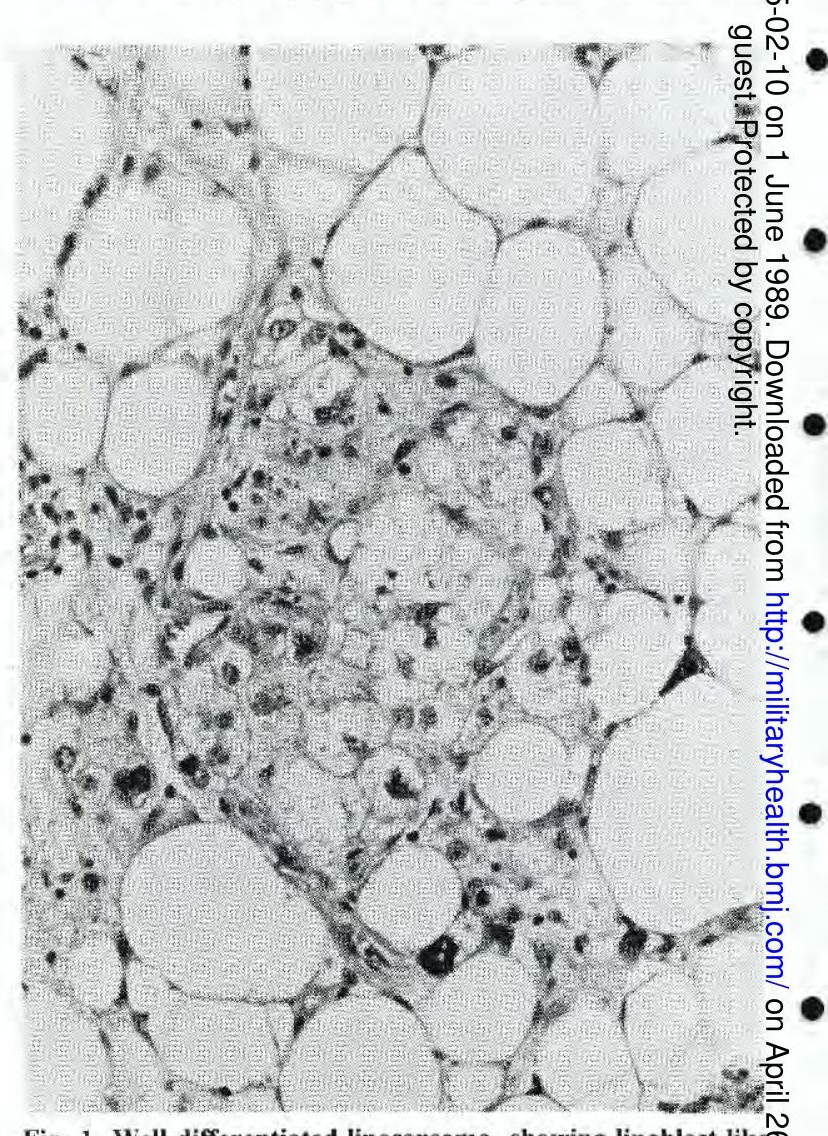

Fig. 1. Well differentiated liposarcoma, showing lipoblast-likẹ cells with vacuolated cytoplasm and bizarre hyperchromation nuclei. 
appears to be adequate treatment. ${ }^{5}$ Recurrence is, however, common in all liposarcomas irrespective of histological type, and often this is due to incomplete surgical removal. The tumour appears well circumscribed, but, in fact, exact boundaries cannot be determined macroscopically and satellite nodules are left behind if attempts are made to "shell out" the tumour. Recurrence may be delayed for $5-10$ years after the initial therapy and 2 cases have been described where well differentiated liposarcomas recurred after 30 years. 6

Postoperative radiotherapy has only been used for metastases, and these are rare in cases of well differentiated tumours. Lymph node dissection is currently not advocated since the pattern of spread is thought to be haematogenous. ${ }^{7}$ In all cases, the planning of subsequent treatment is facilitated by CT scanning.

As this case demonstrates, it is difficult to differentiate malignant and benign spermatic cord swellings clinically. Paratesticular tumours should be considered when any mass is found discrete from the testis regardless of its rate of growth, the presence or absence of pain, and whether or not it transilluminates. It $\frac{c}{15}$ particularly important to bear this in mind during vasectomy counselling.

\section{REFERENCES}

1. SenOH K, Osada Y and Kawachi J. Spermatic cor liposarcoma. Br J Urol 1978; 50: 429.

2. KOSMEHL $\mathbf{H}$ and KatenKamp D. Primare Weichgowebstumoren des Nebenhodens, des paratestikuloren Gewebes und des Samenstranges. Zentralbl Allg Pathol (DDR) $1985, \mathbf{1 3 0}: 5-12$.

3. ENZINGER F M. Histological typing of soft tissue tumougs WHO, Geneva 1969.

4. ENZEINGER F M and WINSLOW D J. Liposarcoma - a studidy of 103 cases. Virchows Arch (Pathol Anat) 1962; 355: $36 \%$ 371.

5. Vorstman B, Black N L and Politano V A. The management of spermatic cord liposarcomas. $J$ Urol (USA) 1984; $131: 66-69$.

6. EnZINGER F M and WeIss S W. Soft tissue tumours., Cgy Mosby 1983 (St Louis).

7. REYES C V. Spermatic cord liposarcoma. Urology 198; 15: $416-417$. 